\title{
Intravitreal aflibercept for choroidal neovascularization associated with chorioretinitis: a pilot study [Corrigendum]
}

Korol AR, Zborovska O, Kustryn T, et al. Intravitreal aflibercept for choroidal neovascularization associated with chorioretinitis: a pilot study. Clin Ophthalmol. 2017;11:1315-1320.

The Acknowledgement implies that Bayer Pharmaceuticals sponsored the study, this is not correct. The acknowledgement should state: The authors take full responsibility for the scope, direction, and content of the manuscript, and have approved the submitted manuscript. Medical writing support was provided by Corey Eagan, MPH, of PAREXEL, and was funded by Bayer Pharmaceuticals.
Clinical Ophthalmology

\section{Publish your work in this journal}

Clinical Ophthalmology is an international, peer-reviewed journal covering all subspecialties within ophthalmology. Key topics include: Optometry; Visual science; Pharmacology and drug therapy in eye diseases; Basic Sciences; Primary and Secondary eye care; Patient Safety and Quality of Care Improvements. This journal is indexed on

\section{Dovepress}

PubMed Central and CAS, and is the official journal of The Society of Clinical Ophthalmology (SCO). The manuscript management system is completely online and includes a very quick and fair peer-review system, which is all easy to use. Visit http://www.dovepress.com/ testimonials.php to read real quotes from published authors. 